\author{
Mikołaj Mielczarek \\ ORCID: 0000-0001-6546-930X \\ Państwowa Wyższa Szkoła Zawodowa w Koninie \\ mikolaj.mielczarek@konin.edu.pl
}

\title{
Efekty fiskalne wprowadzenia podatku bankowego w Polsce
}

\author{
Artykuł nadesłany: 7.01.2020; artykuł zaakceptowany: 6.07.2020 \\ Kody klasyfikacji JEL: F38, H20, H25, K34
}

Keywords: banking sector, bank tax, Financial Activity Tax (FAT), Financial Transaction Tax (FTT), financial institutions

\section{Abstract \\ Fiscal effects of introducing bank tax in Poland}

The article attempts to assess the fiscal effects of the introduction of a bank tax in Poland. From January 2016, a new public tax in Poland has been imposed on some financial institutions, including banks. Similar solutions are also found in some European Union countries. The aim of the article was to implement literature research and legal acts as well as empirical simulation. To accomplish the purpose of the article, literature research and legal acts, as well as empirical simulation were used. The simulation showed that the introduction of a bank tax gives beneficial fiscal effects for the state in the form of additional budget revenues. The construction of the bank tax provided for in Polish law was much more beneficial for the state than the adoption of a solution operating in another EU country. On the other hand, the introduction of a new tax is a rather unfavorable situation for the banking sector, because banks hitherto covered by income taxes and VAT have to bear an additional tax burden from 2016. For the banks themselves, the adoption of a solution found in one of the EU countries would be more favorable than the Polish solution.

\section{Wstęp}

W latach 2010-2017 liczba banków w Polsce zmalała z 646 do 616, ale za to wzrosła wartość zysku netto z ponad 11,4 mld zł w 2010 roku do ponad 13,6 mld zł w 2017 roku (KNF, 2018). Pod koniec 2015 roku rząd zaproponował wprowadzenie dodatkowego opodatkowania sektora finansowego w Polsce, jak ma to miejsce w wielu państwach UE. Głównym celem artykułu jest próba oceny skutków fiskalnych wprowadzenia w Polsce podatku bankowego. 
Objęcie sektora bankowego dodatkowym podatkiem występuje w wielu państwach unijnych. Tematyka ta jest obecnie przedmiotem szczególnego zainteresowania w krajowej literaturze. Wyróżniającymi się autorami są Paweł Dec i Piotr Masiukiewicz (2013) oraz Tomasz Siudek (2011 i 2012).

Artykuł składa się z pięciu części oraz zakończenia. W pierwszej części przedstawiono teoretyczne zagadnienia związane z podatkiem bankowym. W drugiej opisano opodatkowanie sektora bankowego w poszczególnych państwach UE. W części trzeciej scharakteryzowano sytuację sektora bankowego w Polsce. W czwartej omówiono opodatkowanie banków w Polsce zgodnie z zapisami ustawy o podatku od niektórych instytucji finansowych (ustawa z dnia 15 stycznia 2016 r.). Piąta część zawiera symulację skutków fiskalnych wprowadzenia podatku bankowego w Polsce. W zakończeniu dokonano oceny skutków fiskalnych tego projektu.

\section{Podatek bankowy w teorii}

Pojawienie się kryzysu ekonomicznego spowodowało, że państwa postanowiły zwiększyć możliwości oddziaływania na sektor bankowy poprzez wprowadzenie dodatkowych przepisów regulujących działalność banków. Jedną z inicjatyw przewidzianych w ramach regulacji sektora bankowego jest wprowadzenie podatku bankowego, dzięki któremu państwo mogłoby odzyskać część funduszy zaangażowanych $\mathrm{w}$ proces ratowania banków przed upadłością w czasie ostatniego kryzysu oraz zapobiegać wystąpieniu kolejnych kryzysów.

Podatek bankowy jest nową konstrukcją, którą zaczęto w szerszym zakresie stosować w praktyce dopiero po wystąpieniu kryzysu ekonomicznego w 2008 roku. Podatek ten można zdefiniować jako obciążenie publicznoprawne skierowane do określonej grupy podmiotów finansowych, czyli banków i niektórych instytucji parabankowych (Dec, Masiukiewicz, 2013, 17). W szerokim pojęciu za podatek bankowy można uznać zarówno podatki dotyczące niektórych przychodów i operacji, jak i opłaty bankowe. Dlatego też podatek ten może mieć charakter obciążenia pośredniego albo bezpośredniego, a także jest kategorią prawną oraz ekonomiczną. Jednocześnie należy zaznaczyć, że podatek bankowy nie jest podatkiem od określonych dochodów kapitałowych (Syta, 2016, 343).

W teorii można wyodrębnić różne cele podatku bankowego, które będą uzależnione od polityki fiskalnej przyjętej w państwie. Mogą to być cele (Dec, Masiukiewicz, 2013, 18):

— fiskalne — zasilenie budżetu państwa,

— ograniczające ryzyko — podatek od transakcji finansowych lub podatek kryzysowy,

- wyrównanie obciążeń podatkowych danego sektora gospodarki - na przykład jako substytut podatku VAT w bankowości, 
— prorozwojowe - system ulg i zwolnień podatkowych,

— sanacyjne - zasilanie funduszy naprawczych i wykupu złych długów,

— dotyczące stabilizacji systemu finansowego — zasilenie funduszy stabilizacyjnych i gwarancyjnych.

Wśród najważniejszych celów wprowadzenia podatku bankowego można wyróżnić cztery ogólne, czyli (Siudek, 2011, 67-68; Syta, 2016, 343-344):

- zgromadzenie funduszy na wypadek wystąpienia przyszłych kryzysów finansowych,

- zapobieganie niestabilności rynków finansowych oraz ograniczanie rozmiaru ryzyka podejmowanego przez banki,

- możliwość ograniczenia ryzyka bankowego lub nadmiernych wynagrodzeń,

- odzyskanie funduszy zaangażowanych przez rządy w procesie ratowania banków przed ich upadłością w czasie kryzysu ekonomicznego.

W literaturze przedmiotu wyróżnia się najczęściej trzy podstawowe typy podatku bankowego, którymi są: podatek od działalności finansowej (FAT), podatek od transakcji finansowych (FTT) i opłaty bankowe.

Podatek od działalności finansowej (FAT — Financial Activity Tax) ma na celu obciążenie działań podejmowanych przez instytucje finansowe, bez interwencji w bezpośrednie transakcje zawierane na rynku (Komisja Europejska, 2010, 14). FAT jest klasyfikowany jako rodzaj podatku obrotowego o następującej konstrukcji (Narodowy Bank Polski, 2010, 7; Siudek, 2012, 364):

1) FAT 1 - podstawę opodatkowania stanowi suma zysków i wynagrodzeń (przepływy pieniężne netto) z odjęciem inwestycji i bez pomniejszeń o koszty finansowe (zysk pomniejszony o akumulację kapitału i powiększony o koszty wynagrodzeń);

2) FAT 2 - opodatkowaniu podlega wyłącznie renta ekonomiczna, czyli wynagrodzenia i zyski gotówkowe, ale powyżej określonej normy poziomu tak zwanego dochodu czystego (problematyczne jest określenie takiej normy);

3) FAT 3 - opodatkowany jest wyłącznie nadwyżkowy zysk wynikający z operacji obciążonych nadmiernym ryzykiem, a próg zysków gotówkowych jest ustalany na podstawie tak zwanego nadwyżkowego zwrotu z kapitału własnego (niezbędne okazuje się zatem ustalenie normy w tym zakresie).

FAT w najprostszym ujęciu oznacza naliczanie podatku od kwoty zysku instytucji finansowej i kwoty wynagrodzeń wypłacanych przez tę instytucję. Jest to podatek jednostopniowy, pobierany od instytucji finansowej tylko raz i jednocześnie niepozostawiający nabywcy towaru/usługi od instytucji finansowej prawa do odliczenia zapłaconego podatku. Do obliczenia podstawy opodatkowania FAT jest istotne zdefiniowanie sposobu liczenia przepływów pieniężnych, gdyż mogą $\mathrm{w}$ tym zakresie występować różnice $\mathrm{w}$ poszczególnych krajach. Zawężona koncepcja opodatkowania działalności finansowej sprowadza się do nałożenia podatku wyłącznie od wartości uzyskiwanych w rozmiarach wyższych od przecięt- 
nych, czyli od czystej renty (Zygierewicz, 2012, 493-494). Problemem w takim podejściu jest prawidłowe określenie ponadprzeciętnej wielkości zysku i wynagrodzeń w gospodarce. Podatek od działalności finansowej dotyczy tylko instytucji finansowych oraz ich zysków i wypłaconych wynagrodzeń, a nie wszystkich podmiotów biorących udział w transakcjach finansowych.

W zakresie podatku od transakcji finansowych (FTT - Financial Transaction Tax) przedmiotem opodatkowania są transakcje dotyczące instrumentów finansowych, a sama danina ma charakter podatku obrotowego. Wprowadzenie FTT miało na celu (Marcinkowska, 2011, 104; Zygierewicz, 2012, 495):

- poprawienie funkcji rynku,

- ograniczenie ryzyka na rynku finansowym, w tym ultrakrótkoterminowego handlu,

— zapobieganie tworzeniu się baniek spekulacyjnych na rynku aktywów finansowych,

— zapewnienie wpływów do budżetu państwa, w tym lepszy przepływ pieniędzy z sektora finansowego do budżetu państwa,

— zmniejszenie poziomu długu rządowego i powiązanego z tym ryzyka.

Podatek od transakcji finansowych może przyjąć następującą konstrukcję (Komisja Europejska, 2010, 12-13):

1) FTT I (szeroka formuła) - podatek dotyczy obrotu instrumentami finansowymi (akcjami, obligacjami, instrumentami pochodnymi), a podstawę opodatkowania stanowi wartość transakcji (dla instrumentów prostych) lub wartość kontraktu (dla instrumentów złożonych);

2) FTT II (wąska formuła) - podatek dotyczy wyłącznie obrotu akcjami i obligacjami ze względu na problemy związane z wyceną instrumentów pochodnych oraz kontrowersje związane z ustaleniem podstawy opodatkowania.

W praktyce mogą występować różne modele FTT, co przedstawia tabela 1.

Tabela 1. Modele podatku od transakcji finansowych

\begin{tabular}{|c|c|}
\hline Model podatku & Charakterystyka \\
\hline $\begin{array}{l}\text { podatek od transakcji na } \\
\text { papierach wartościowych } \\
\text { (STT - Securities } \\
\text { Transactions Tax) }\end{array}$ & $\begin{array}{l}\text { — obrót papierami wartościowymi (wszystkimi lub wybranymi } \\
\text { rodzajowo) } \\
\text { — może obejmować emisje lub odnosić się do obrotu wtórnego, } \\
\text { — może występować jako stała opłata od transakcji lub staw- } \\
\text { ka procentowa wartości instrumentów finansowych będących } \\
\text { przedmiotem handlu }\end{array}$ \\
\hline $\begin{array}{l}\text { podatek od transakcji } \\
\text { w walutach obcych (CTT - } \\
\text { Currency Transaction Tax) }\end{array}$ & $\begin{array}{l}\text { — obrót papierami wartościowymi } \\
\text { — nakładany na transakcje walutowe lub instrumenty pochodne }\end{array}$ \\
\hline $\begin{array}{l}\text { opłata za kapitał (capital } \\
\text { levy, registiation tax) }\end{array}$ & $\begin{array}{l}\text { — podatek nakładany na przyrost kapitałów (wpłaty lub dopłaty } \\
\text { do kapitału, emisja papierów wartościowych itp.) }\end{array}$ \\
\hline
\end{tabular}

Ekonomia - Wroclaw Economic Review 26/, 2020

(C) for this edition by CNS 


\begin{tabular}{|c|c|}
\hline Model podatku & Charakterystyka \\
\hline $\begin{array}{l}\text { podatek od transakcji } \\
\text { bankowych (BTT - Bank } \\
\text { Transaction Tax) }\end{array}$ & $\begin{array}{l}\text { — podatek od lokat bankowych, wypłat i wpłat na rachunki ban- } \\
\text { kowe, innych transakcji (na przykład obrót derywatami) } \\
\text { — nakładany w formie stopy procentowej od wartości transakcji }\end{array}$ \\
\hline $\begin{array}{l}\text { podatek od składek } \\
\text { ubezpieczeniowych (IPT - } \\
\text { Insurance Premium Taxes) }\end{array}$ & $\begin{array}{l}\text { — podatek nakładany na instytucje prowadzące działalność } \\
\text { ubezpieczeniową }\end{array}$ \\
\hline $\begin{array}{l}\text { podatek od transakcji } \\
\text { dotyczących nieruchomości } \\
\text { (Real Estate Transaction } \\
\text { Tax) }\end{array}$ & $\begin{array}{l}\text { — podatek nakładany na transakcje związane z nieruchomoś- } \\
\text { ciami }\end{array}$ \\
\hline
\end{tabular}

Źródło: opracowanie własne na podstawie Marcinkowska, 2011, 105; Zygierewicz, 2012, 495-496.

W wpadku opłat bankowych lub tak zwanych stabilizacyjnych celem ich nakładania może być motywowanie do ograniczenia ryzyka lub zgromadzenie środków na funduszu naprawczym (bądź w budżecie państwa) na wypadek kryzysu (Dec, Masiukiewicz, 2013, 42). Opłata bankowa może mieć następujące formy (Juszczyk, Snarski, 2011, 51-53):

1) opłata bankowa lub ostrożnościowa (FSC - Financial Stability Contrubution, bank levy) — może się składać z jednego lub dwóch elementów, a podstawę opodatkowania tworzą pasywa instytucji finansowej z pewnymi wyłączeniami; stawka podatku może być zależna od ryzyka, jakie dana instytucja wnosi do systemu finansowego (zwykle jest to trudne do określenia);

2) opłata za współtworzenie ryzyka systemowego (SCC) - model parapodatku trudny do zastosowania w praktyce; opłata powinna być zależna od wartości aktywów danej instytucji oraz od charakteru i skali ponoszonego ryzyka, a także od złożoności działalności podmiotu i jego powiązań;

3) tak zwane podatki korekcyjne:

a) podatek od ryzyka systemowego - opiera się na oczekiwanym krańcowym udziale w ryzyku systemu finansowego,

b) podatek od krótkoterminowych zobowiązań „hurtowych” — podstawą opodatkowania jest różnica między akceptowalnym kosztem zobowiązań średnioterminowych a kosztem zobowiązań krótkoterminowych.

\section{Podatek bankowy w państwach Unii Europejskiej}

Danina publiczna obciążająca banki w formie podatku bankowego lub też opłaty bankowej występuje w większości państw członkowskich Unii Europejskiej. Tabela 2 przedstawia państwa, w których występuje podatek bankowy ze wskazaniem jego formy. 
Tabela 2. Podatek bankowy w państwach członkowskich Unii Europejskiej

\begin{tabular}{|c|c|c|c|c|}
\hline Państwo & $\begin{array}{l}\text { Podatek } \\
\text { bankowy }\end{array}$ & $\begin{array}{c}\text { Opłata } \\
\text { bankowa }\end{array}$ & $\begin{array}{c}\text { Rok } \\
\text { wprowadzenia }\end{array}$ & Wpływy z daniny \\
\hline Austria & + & & 2011 & budżet państwa \\
\hline Belgia & & + & 2012 & fundusz stabilizacyjny \\
\hline Cypr & + & & 2011 & fundusz stabilizacyjny \\
\hline Finlandia & + & & 2013 & budżet państwa \\
\hline Francja & + & & 2011 & budżet państwa \\
\hline Holandia & + & & 2012 & budżet państwa \\
\hline Łotwa & & + & 2011 & budżet państwa \\
\hline Niemcy & + & & 2011 & fundusz stabilizacyjny \\
\hline Polska & + & & 2016 & budżet państwa \\
\hline Portugalia & + & & 2011 & budżet państwa \\
\hline Rumunia & + & & 2011 & fundusz kompensacyjny \\
\hline Słowacja & + & & 2012 & budżet państwa \\
\hline Słowenia & + & & 2011 & budżet państwa \\
\hline Szwecja & & + & 2009 & fundusz stabilizacyjny \\
\hline Węgry & + & & 2010 & budżet państwa \\
\hline Wielka Brytania $^{1}$ & + & & 2011 & budżet państwa \\
\hline Włochy & + & & 2013 & budżet państwa \\
\hline
\end{tabular}

131 stycznia 2020 roku nastąpił brexit, czyli rozpoczęcie praktycznej realizacji czynności związanych z wystąpieniem Wielkiej Brytanii z Unii Europejskiej.

Źródło: opracowanie własne na podstawie Dec, Masiukiewicz, 2013, 67-81; Gajewski, 2016, 14; Kil, Ślusarczyk, 2014, 128-129; Martysz, Bartlewski, 2018, 113; Syta, 2016, 344-348; Szolno-Koguc, Twarowska, 2015; Wojciuk, 2017, 30-32).

W większości państw członkowskich UE daniną publiczną, jaką zostały objęte instytucje finansowe, jest podatek bankowy, a w zaledwie trzech państwach jest to opłata bankowa. Najwcześniej dodatkową daninę obciążającą instytucje finansowe wprowadziły Szwecja i Węgry, a najpóźniej Polska. W większości wskazanych w tabeli 2 państw dochody z podatku/opłaty bankowego/-ej wpływały do budżetu państwa, a w czterech państwach — do funduszu stabilizacyjnego.

Austriackim podatkiem bankowym objęte zostały: banki krajowe, zagraniczne oddziały banków krajowych i oddziały zagranicznych banków prowadzących działalność w Austrii. Opodatkowaniu podlegają banki o pasywach powyżej 1 mld euro, a poniżej tej kwoty instytucja finansowa jest zwolniona z obowiązku 
podatkowego. Podstawą opodatkowania są pasywa banku z wyłączeniem kapitału własnego, rezerw i depozytów gwarantowanych. Stawka podatku wynosi $0,055 \%$ dla pasywów od 1 do 20 mld euro oraz $0,09 \%-0,11 \%$ dla pasywów powyżej 20 mld euro, natomiast derywaty zostały objęte stawką $0,013 \%$ ich nominalnej wartości. Cechą charakterystyczną podatku bankowego w Austrii jest, że instytucje finansowe mogą go zaliczyć do kosztów operacyjnych (Wojciuk, 2017, 32).

W Belgii obowiązuje stabilizacyjna opłata bankowa (FSC), która dotyczy banków krajowych i ich oddziałów zagranicznych. Podstawę FSC tworzą pasywa banku obliczone według stanu na koniec grudnia danego roku, które są pomniejszane o kapitały własne oraz gwarantowane depozyty. Stawka opłaty bankowej wynosi $0,035 \%$. Instytucje finansowe nie mogą zaliczyć FSC do kosztów uzyskania przychodów (Dec, Masiukiewicz, 2013, 69-70).

Na Cyprze podatkiem bankowym objęto: banki krajowe, zagraniczne oddziały banków działających w kraju oraz grupy niebankowe, które posiadają bank (ale z zastrzeżeniem, że grupa działa tylko na rynku krajowym). Z podatku zwolnione są zagraniczne oddziały banków krajowych. Podstawę opodatkowania tworzą pasywa, które są pomniejszone o kapitały własne i gwarantowane depozyty. Stawka podatku wynosi $0,15 \%$, a sam podatek nie może być zaliczony przez instytucje finansowe do kosztów uzyskania przychodów (Martysz, Bartlewski, 2018, 113).

Fiński podatek bankowy został nałożony na krajowe banki depozytowe oraz ich filie, a oddziały zagranicznych banków działające w Finlandii zostały zwolnione $\mathrm{z}$ obowiązku podatkowego. Podstawę opodatkowania tworzą aktywa banku ważone ryzykiem, a stawka podatkowa wynosi $0,125 \%$ wartości aktywów. Banki zobowiązane są do zapłaty podatku bankowego w terminie do 30 kwietnia każdego roku, a sam podatek nie może być wliczony do kosztów uzyskania przychodów (Dec, Masiukiewicz, 2013, 79-80).

Francuski podatek bankowy dotyczy banków z zastrzeżeniem, że francuskie grupy bankowe oraz filie banków zagranicznych płacą podatek na poziomie skonsolidowanym. Z obowiązku podatkowego zostały zwolnione oddziały banków zagranicznych Europejskiego Obszaru Gospodarczego, które działają na rynku francuskim. Podstawą opodatkowania są pasywa będące nadwyżką funduszy własnych banku powyżej $500 \mathrm{mln}$ euro. Stawka podatku bankowego została ustalona na poziomie $0,25 \%$, przy czym obowiązywała ona do końca 2012 roku. Od 1 stycznia 2013 roku stawka francuskiego podatku wynosiła $0,5 \%$, ale miała być stopniowo redukowana do poziomu 0,141\% w 2019 roku — obecnie wynosi $0,222 \%$. Podatek ten jest kosztem uzyskania przychodu dla instytucji, które są nim objęte (Martysz, Bartlewski, 2018, 113; Syta, 2016, 345; Szolno-Koguc, Twarowska, 2015, 45; Wojciuk, 2017, 32).

W Holandii podatkiem bankowym zostały objęte: banki krajowe, zagraniczne oddziały banków krajowych oraz oddziały zagranicznych banków prowadzące działalność w kraju. Podstawę opodatkowania oblicza się według jednostkowego lub skonsolidowanego bilansu i zawiera ona część mniej istotnych pasywów przekracza- 
jących 20 mld euro. Do podstawy podatku nie zalicza się między innymi kapitałów własnych, gwarantowanych depozytów oraz innych ubezpieczonych zobowiązań. W holenderskim podatku bankowym występują dwie stawki podatku. Podstawowa wynosi $0,044 \%$, natomiast stawka $0,022 \%$ dotyczy tylko zobowiązań długoterminowych. Dodatkowo przyjęto, że jeśli jeden z członków zarządu banku otrzymuje niestałą część wynagrodzenia przekraczającą 25\% jego stałych dochodów, to wskazane stawki muszą być pomnożone przez współczynnik 1,1. Podatek bankowy nie może być wliczony do kosztów uzyskania przychodów (Dec, Masiukiewicz, 2013, 73).

Łotwa jest jednym z trzech państw UE, które wprowadziły opłatę bankową jako formę obciążenia instytucji finansowych. Zostały nią objęte: banki krajowe, oddziały zagraniczne krajowych banków, a także oddziały banków zagranicznych działające na Łotwie. Podstawę opodatkowania tworzą zobowiązania banków ogółem pomniejszone o gwarantowane depozyty. Stawka opłaty bankowej wynosi $0,072 \%$ rocznie (Szolno-Koguc, Twarowska, 2015, 17).

W Niemczech podatkiem bankowym są objęte: banki krajowe, oddziały zagraniczne banków krajowych oraz podmioty zależne banków zagranicznych funkcjonujące $\mathrm{w}$ kraju. $\mathrm{Z}$ obowiązku podatkowego są wyłączone oddziały banków zagranicznych działających w Niemczech. Podstawę opodatkowania stanowią pasywa banku pomniejszone o fundusze własne i gwarantowane zobowiązania wobec klientów. Natomiast w przypadku derywatów podstawą opodatkowania jest ich wartość nominalna. W niemieckim rozwiązaniu określono cztery stawki podatku:

— $0,02 \%$ od zobowiązań poniżej 10 mld euro,

- $0,03 \%$ od zobowiązań z przedziału $10-100$ mld euro,

- $0,04 \%$ od zobowiązań z przedziału 100-200 mld euro,

— $0,05 \%$ od zobowiązań z przedziału 200-300 mld euro,

- $0,06 \%$ od zobowiązań powyżej 300 mld euro,

$-0,003 \%$ dla derywatów.

Aby ograniczyć nadmierne opodatkowanie banków, założono, że podatek bankowy nie może przekraczać $20 \%$ zysku netto. Natomiast banki niemające zysku netto zamiast podatku wpłacają na fundusz restrukturyzacyjny co najmniej $5 \%$ kwoty opłaty naliczanej zgodnie z podanymi stawkami. Podatek płacony jest do 30 września każdego roku (Szolno-Koguc, Twarowska, 2015, 31-33).

Portugalskiemu podatkowi bankowemu podlegają: banki krajowe oraz ich zagraniczne oddziały lub filie, a także zagraniczne oddziały banków spoza UE. Podatek ten nie obejmuje natomiast grup kapitałowych. Podstawę opodatkowania tworzą pasywa banku z wyłączeniem kapitałów pierwszej i drugiej kategorii (Tier 1 i Tier 2) oraz depozytów gwarantowanych przez Portugalski Fundusz Gwarantowania Depozytów. Sam podatek nie może być zaliczony do kosztów uzyskania przychodów. Stawki podatku bankowego zostały ustalone progresywnie i wynoszą (Martysz, Bartlewski, 2018, 113; Syta, 2016, 346):

$-0,01 \%-0,085 \%$ - dla pasywów pomniejszonych o kapitały Tier 1 i Tier 2 oraz gwarantowane depozyty,

— 0,001\%-0,0003\% — od wielkości derywatów. 
W Rumunii podatkiem bankowym zostały objęte wszystkie banki, a podstawą naliczania daniny są całkowite pasywa pomniejszone o zobowiązania gwarantowane. Stawka podatku wynosi $0,1 \%$, a sam podatek nie może być zaliczony do kosztów podatkowych (Gajewski, 2016, 14).

Podmiotamipodlegającymipodatkowibankowemuna Słowacji są: bankikrajowe $i$ ich oddziały zagraniczne, a także oddziały zagranicznych banków działających w kraju. Podstawę opodatkowania tworzą pasywa banku, pomniejszane o: kapitały własne, zobowiązania długoterminowe wobec banków i inne depozyty podlegające specjalnej ochronie na podstawie przepisów prawa słowackiego lub innego państwa członkowskiego UE. Stawka podatku bankowego wynosi 0,2\% (w latach 2012 2014 stawka podatku wynosiła $0,4 \%$ ), a sam podatek może być zaliczony do kosztów uzyskania przychodów (Dec, Masiukiewicz, 2013, 80-81; Wojciuk, 2017, 32).

Podatkiem bankowym w Słowenii objęto banki krajowe i oddziały banków zagranicznych działających w kraju. Podatkowi nie podlegają natomiast zagraniczne oddziały banków krajowych. Podstawę opodatkowania stanowią całkowite aktywa banku, które wykazano w sprawozdaniu finansowym, a obliczane jako ich średnia wartość na ostatni dzień każdego miesiąca roku kalendarzowego. Stawka podatku wynosi $0,1 \%$ wielkości wyliczonych aktywów, a pułap wielkości podatku założono na $0,167 \%$ od salda kredytów udzielonych instytucjom niefinansowym (Dec, Masiukiewicz, 2013, 80).

W Szwecji instytucje finansowe zostały objęte opłatą bankową. Opłacie tej podlegają: banki krajowe, ich zagraniczne oddziały oraz podmioty zależne banków zagranicznych, które mają siedzibę w Szwecji. Opłata bankowa jest naliczana od wielkości pasywów banku pomniejszonych o kapitał własny oraz niektóre papiery dłużne (o charakterze długu podporządkowanego). Kwota zapłaconej opłaty bankowej stanowi koszt uzyskania przychodu w podatku CIT. Stawka opłaty wynosi od 2011 roku 0,036\%, ale ze względu na trudną sytuację gospodarczą w 2009 i 2010 roku stawka w tych latach wynosiła 0,018\% (Szolno-Koguc, Twarowska, 2015, 73-74).

Na Węgrzech podatkiem bankowym objęto: banki, instytucje kredytowe, ubezpieczycieli oraz inne instytucje świadczące usługi finansowe. Podstawy obliczania i stawki podatku bankowego są zróżnicowane ze względu na rodzaj instytucji:

— banki płacą $0,15 \%$ od aktywów netto, jeśli te nie przekraczają 50 mld forintów bądź $0,21 \%$ od części aktywów przekraczających limit,

- ubezpieczyciele płacą $6,2 \%$ od skorygowanego przychodu z ubezpieczeń,

- firmy finansowe płacą $6,5 \%$ od przychodów odsetkowych oraz przychodów z opłat i prowizji,

— firmy inwestycyjne i zarządzające funduszami venture capital płacą 5,6\% od skorygowanych przychodów netto,

— firmy zarządzające funduszami inwestycyjnymi płacą $0,028 \%$ od wartości netto zarządzanych aktywów.

Ponadto od 1 stycznia 2013 roku na Węgrzech obowiązuje podatek od transakcji finansowych, którym objęto każdą operację finansową przeprowadzaną przez banki komercyjne i Bank Centralny Węgier. Stawka podatku wynosi 6 tys. 
forintów od każdej transakcji oraz $0,1 \%$ dla operacji giełdowych i na rynku obligacji (Dec, Masiukiewicz, 2013, 74-77; Martysz, Bartlewski, 2018, 113).

Brytyjski podatek bankowy został wprowadzony w 2011 roku, a objęte nim są banki, których zobowiązania przekraczają sumę 20 mld funtów, według następujących kryteriów:

— zobowiązania grup bankowych w Wielkiej Brytanii i towarzystw mieszkaniowych są ustalane na poziomie skonsolidowanym,

— uwzględniane są zobowiązania banków brytyjskich, które działają w ramach grup niebankowych,

- brane są pod uwagę zobowiązania ujmowane w zagregowanych bilansach podmiotów zależnych oraz oddziałów zagranicznych banków i grup bankowych działających w Wielkiej Brytanii,

— podatek dotyczy banków macierzystych oraz ich oddziałów i podmiotów zależnych, a także podmiotów zależnych banków zagranicznych oraz ich oddziałów.

Omawiany podatek dotyczy banków macierzystych, ich oddziałów i podmiotów zależnych oraz oddziałów banków zagranicznych działających w Wielkiej Brytanii. Podatek bankowy nie jest kosztem uzyskania przychodu, a nalicza się go od zobowiązań pomniejszonych o: kapitał podstawowy, gwarantowane depozyty, repo zabezpieczone papierami wartościowymi o zobowiązania wynikające $\mathrm{z}$ określonej działalności ubezpieczeniowej w ramach grup bankowych. Stawki podatku wynoszą (Martysz, Bartlewski, 2018, 113; Szolno-Koguc, Twarowska, 2015, 20-22; Syta, 2016, 345):

- $0,16 \%$ dla zobowiązań banku,

— $0,08 \%$ dla źródeł finansowania pozyskanych na rynku międzybankowym i zapadających w terminie dłuższym niż rok.

We Włoszech 24 grudnia 2012 roku parlament zatwierdził ustawę budżetową, która wprowadziła włoski podatek od transakcji finansowych (FTT). Podatek ten obowiązuje od 1 marca 2013 roku i dotyczy przeniesienia praw własności akcji oraz innych udziałowych papierów wartościowych wyemitowanych przez spółki będące rezydentami Włoch, a także innych instrumentów finansowych opartych na akcjach $\mathrm{i}$ innych udziałowych papierach wartościowych. Włoskim podatkiem objęte są:

- papiery wartościowe wyemitowane we Włoszech,

- handel wysokiej częstotliwości instrumentami finansowymi wyemitowanymi we Włoszech (od 1 marca 2013 roku),

— instrumenty pochodne oraz handel wysokiej częstotliwości instrumentami tego typu.

Podatek ma zastosowanie do akcji i podobnych instrumentów finansowych wyemitowanych przez spółki zarejestrowane we Włoszech, przy czym akcje spółek o kapitalizacji rynkowej poniżej $500 \mathrm{mln}$ euro są zwolnione z podatku. Stawka podatku od transakcji na rynku regulowanym wynosi $0,1 \%$, natomiast od transakcji na rynkach pozagiełdowych $-0,2 \%$. Z podatku wyłączone są natomiast (Szolno-Koguc, Twarowska, 2015, 54-55): 
- transakcje z kontrahentami instytucjonalnymi,

— transakcje realizowane przez animatorów rynku (market maker),

— transakcje wynikające z zawartych umów o płynności (liquidity contracts),

- obowiązkowe fundusze emerytalne lub instytucje zabezpieczenia społecznego z siedzibą w państwach członkowskich UE lub EOG.

\section{Sektor bankowy w Polsce}

Analiza sytuacji polskiego sektora bankowego została oparta na liczbie banków i zatrudnionych osób, a także wielkościach wynikających z bilansu oraz rachunku zysków i strat. Tabela 3 przedstawia dane dotyczące sektora bankowego w Polsce w latach 2010-2018.

W latach 2010-2018 liczba banków w Polsce zmniejszyła się z 646 do 613, a liczba zatrudnionych w sektorze bankowym z ponad 176 tys. do prawie 163,6 tys. Co do wielkości wynikających z bilansu banków najlepiej sytuacja wyglądała w kwestii sumy bilansowej i wartości funduszy własnych. W obu tych przypadkach występował rokroczny wzrost ich wielkości. Odnośnie do wartości aktywów i pasywów największy wzrost (o 11,64\%) wystąpił w roku 2011. Natomiast co do funduszy własnych największy ich przyrost (o 13,68\%) wystąpił w roku 2012. Wartość depozytów oraz kredytów i pożyczek również rokrocznie wzrastała. Największy wzrost wartości depozytów (o 10,18\%) wystąpił w roku 2011. W tym samym roku wystąpił największy wzrost wartości kredytów i pożyczek (o 14,79\%). Ostatnią wielkością poddaną analizie jest wynik netto, który stanowi różnicę pomiędzy zyskiem netto a stratą netto. W badanych latach największy wzrost tej wielkości (o 36,07\%) wystąpił w roku 2011 w wyniku największego wzrostu zysku netto, a największy spadek (o 29,53\%) — w roku 2015.

\section{Założenia polskiego podatku bankowego}

W Polsce instytucje finansowe zostały objęte podatkiem bankowym od 1 lutego 2016 roku na podstawie ustawy z 15 stycznia 2016 r. o podatku od niektórych instytucji finansowych. Wpływy z podatku bankowego zgodnie z ustawą są dochodem budżetu państwa.

Podatkiem bankowym są objęte: banki krajowe, oddziały banków zagranicznych, oddziały instytucji kredytowych, spółdzielcze kasy oszczędnościowo-kredytowe, krajowe zakłady ubezpieczeń, krajowe zakłady reasekuracji, oddziały zagranicznych zakładów ubezpieczeń i zagranicznych zakładów reasekuracji, główne oddziały zagranicznych zakładów ubezpieczeń i zagranicznych zakładów reasekuracji oraz instytucje pożyczkowe. Przedmiotem opodatkowania są aktywa podmiotów objętych podatkiem (ustawa z dnia 15 stycznia 2016 r., art. 3-4). 


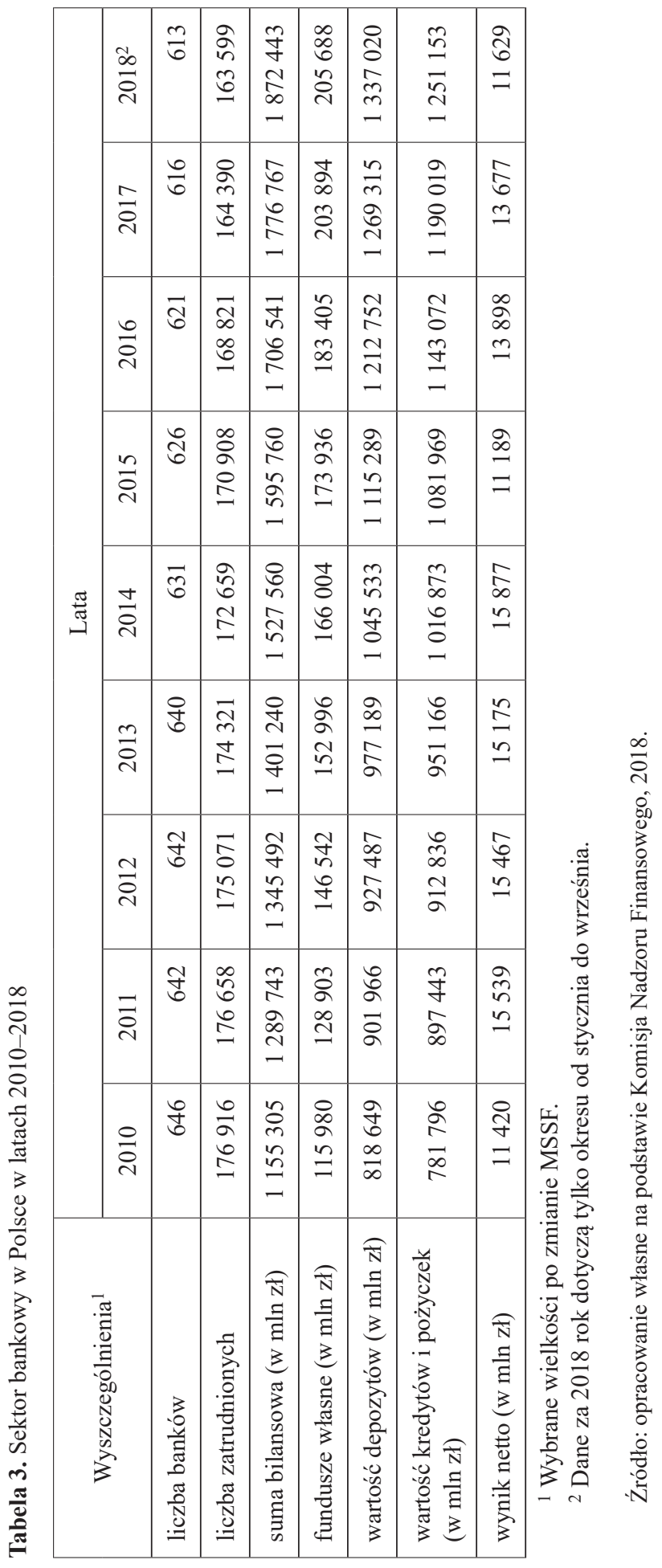


Podstawę opodatkowania stanowi nadwyżka sumy wartości aktywów wynikająca z zestawienia obrotów i sald, ustalonego na ostatni dzień miesiąca, ponad (ustawa z dnia 15 stycznia 2016 r., art. 5):

— kwotę 4 mld zł dla banków krajowych, oddziałów banków zagranicznych, oddziałów instytucji kredytowych oraz spółdzielczych kas oszczędnościowo-kredytowych,

— kwotę 2 mld zł dla krajowych zakładów ubezpieczeń, krajowych zakładów reasekuracji, oddziałów zagranicznych zakładów ubezpieczeń i zagranicznych zakładów reasekuracji, głównych oddziałów zagranicznych zakładów ubezpieczeń oraz zagranicznych zakładów reasekuracji,

— kwotę $200 \mathrm{mln}$ zł dla instytucji pożyczkowych.

Przy tym wskazaną podstawę opodatkowania obniża się o (ustawa z dnia 15 stycznia 2016 r., art. 5):

- wartość funduszy własnych dla banków krajowych, oddziałów banków zagranicznych, oddziałów instytucji kredytowych oraz spółdzielczych kas oszczędnościowo-kredytowych,

— wartość środków finansowych zgromadzonych na wszystkich rachunkach zrzeszonych banków spółdzielczych, prowadzonych przez podatnika dla banków krajowych,

- kwoty podwyższenia funduszu własnego w miesiącu, za który ustala się podstawę opodatkowania dla banków krajowych, oddziałów banków zagranicznych, oddziałów instytucji kredytowych oraz spółdzielczych kas oszczędnościowo-kredytowych,

— wartość aktywów nabytych przez podatnika od NBP, a stanowiących zabezpieczenie kredytu refinansowego udzielonego przez NBP dla banków krajowych, oddziałów banków zagranicznych oraz oddziałów instytucji kredytowych,

- wartość aktywów w postaci skarbowych papierów wartościowych, dla banków krajowych, oddziałów banków zagranicznych, oddziałów instytucji kredytowych oraz spółdzielczych kas oszczędnościowo-kredytowych.

Jeżeli podstawa opodatkowania będzie wyrażona w walucie obcej, to do przeliczenia na złote kwot wyrażonych w danej walucie wykorzystuje się średni kurs danej waluty obcej ogłoszony przez NBP na ostatni dzień roboczy poprzedzający dzień, na który ustalana będzie podstawa opodatkowania. Stawka podatku bankowego wynosi $0,0366 \%$ podstawy opodatkowania miesięcznie (ustawa z dnia 15 stycznia 2016 r., art. 6-7).

Instytucje finansowe objęte podatkiem bankowym są zobowiązane bez wezwania właściwego organu podatkowego do złożenia deklaracji podatkowej według ustalonego wzoru do właściwego naczelnika urzędu skarbowego, a także do obliczenia i wpłacenia podatku na rachunek właściwego urzędu skarbowego do 25 dnia miesiąca następującego po miesiącu, którego podatek dotyczy. Właściwym organem podatkowym w zakresie podatku bankowego jest naczelnik urzędu skarbowego właściwy miejscowo ze względu na siedzibę podatnika, a jeżeli bra- 
kuje możliwości ustalenia właściwego organu podatkowego, to wtedy właściwym organem podatkowym jest Naczelnik Drugiego Urzędu Skarbowego Warszawa-Śródmieście (ustawa z dnia 15 stycznia 2016 r., art. 8-9).

Artykuły 10-11 ustawy (ustawa z dnia 15 stycznia 2016 r.) wskazują, że z podatku bankowego w Polsce zwolnione są następujące podmioty:

a) banki państwowe,

b) w stosunku do których KNF wydała decyzję (do czasu jej wykonania):

— w sprawach, o których mowa w ustawie z dnia 21 lipca 2006 r. o nadzorze nad rynkiem finansowym,

- o zawieszeniu działalności spółdzielczej kasy oszczędnościowo-kredytowej, o której mowa w ustawie z dnia 5 listopada 2009 roku o spółdzielczych kasach oszczędnościowo-kredytowych;

c) podatnicy objęci:

- wdrożonym planem naprawy, w przypadku zaistnienia okoliczności, o których mowa w ustawie z dnia 29 sierpnia 1997 r. - Prawo bankowe,

- programem postępowania naprawczego, o którym mowa w ustawie $\mathrm{z}$ dnia 5 listopada 2009 r. o spółdzielczych kasach oszczędnościowo-kredytowych,

- planem naprawczym, o którym mowa w ustawie $\mathrm{z}$ dnia 11 września 2015 r. o działalności ubezpieczeniowej i reasekuracyjnej, lub krótkoterminowym planem finansowym, o którym mowa w tej ustawie.

\section{Efekty fiskalne wprowadzenia podatku bankowego w Polsce}

Wprowadzenie podatku bankowego w Polsce niesie za sobą daleko idące efekty fiskalne. Symulacja tych efektów została przeprowadzona w trzech ujęciach:

1) w ogólnym z zastosowaniem rozwiązań występujących w różnych państwach UE;

2) w ogólnym z zastosowaniem różnych przykładowych stawek podatku przy wskazanej w ustawie podstawie opodatkowania;

3) w ogólnym z zastosowaniem różnych podstaw opodatkowania przy wskazanej w ustawie stawce podatku.

Symulację oparto na następujących założeniach:

1) do obliczeń przyjęto wielkości księgowe za 2017 rok podane dla całego sektora bankowego w Polsce, przez KNF w zestawieniu po zmianach MSSF;

2) przyjęte stawki podatku oraz podstawy opodatkowania opierają się na rozwiązaniach pochodzących z omówionych wcześniej państw UE;

3) w przypadku Polski przyjęto, że wysokość podatku będzie stała i opiera się na podstawie wysokości w sprawozdaniu z wykonania budżetu państwa za 2017 rok opublikowanym przez Ministerstwo Finansów;

4) do obliczeń przyjęto, że stawka podatku w Polsce wynosi 0,4392\%, czyli dwunastokrotność miesięcznej stawki 0,0366\%. 
Tabela 4 przedstawia wpływy z podatku bankowego w Polsce przy zastosowaniu konstrukcji podatku występującej w różnych państwach UE.

Tabela 4. Podatek bankowy w Polsce przy zastosowaniu rozwiązań występujących w państwach Unii Europejskiej

\begin{tabular}{|c|c|c|c|}
\hline Kraj & Stawka podatku [\%] & Podstawa opodatkowania w zł & Podatek w zł \\
\hline \multirow{3}{*}{ Austria } & 0,055 & 303558568032,00 & 166957212,42 \\
\hline & 0,090 & 303558568032,00 & 273202711,23 \\
\hline & 0,110 & 303558568033,00 & 333914424,84 \\
\hline Belgia & 0,035 & 303558568032,00 & 106245498,81 \\
\hline Cypr & 0,150 & 303558568032,00 & 455337852,05 \\
\hline Finlandia & 0,125 & 1042536847238,00 & 1303171059,05 \\
\hline \multirow{2}{*}{ Francja } & 0,222 & 1572873788133,00 & 3491779809,66 \\
\hline & 0,141 & 1572873788133,00 & 2217752041,27 \\
\hline Holandia & 0,044 & 303558568032,00 & 133565769,93 \\
\hline Łotwa & 0,072 & 303558568032,00 & 218562168,98 \\
\hline \multirow{5}{*}{ Niemcy } & 0,020 & 303558568032,00 & 60711713,61 \\
\hline & 0,030 & 303558568032,00 & 91067570,41 \\
\hline & 0,040 & 303558568032,00 & 121423427,21 \\
\hline & 0,050 & 303558568032,00 & 151779284,02 \\
\hline & 0,060 & 303558568032,00 & 182135140,82 \\
\hline Polska & & & 4341221000,00 \\
\hline \multirow{2}{*}{ Portugalia } & 0,010 & 303558568032,00 & 30355856,80 \\
\hline & 0,085 & 303558568033,00 & 258024782,83 \\
\hline Rumunia & 0,100 & 507452222194,00 & 507452222,19 \\
\hline Słowacja & 0,200 & 303558568032,00 & 607117136,06 \\
\hline Słowenia & 0,100 & 1776767442295,00 & 1776767442,30 \\
\hline Szwecja & 0,036 & 1572873788 133,00 & 566234563,73 \\
\hline \multirow{2}{*}{ Węgry } & 0,150 & 1776767442295,00 & 2665151163,44 \\
\hline & 0,210 & 1776767442295,00 & 3731211628,82 \\
\hline \multirow{2}{*}{ Wielka Brytania } & 0,160 & 303558568032,00 & 485693708,85 \\
\hline & 0,080 & 303558568032,00 & 242846854,43 \\
\hline \multirow{2}{*}{ Włochy } & 0,100 & 419265932703,00 & 419265932,70 \\
\hline & 0,200 & 419265932703,00 & 838531865,41 \\
\hline
\end{tabular}

Źródło: opracowanie własne na podstawie Komisja Nadzoru Finansowego, 2018.

Ekonomia - Wroclaw Economic Review 26/, 2020

(C) for this edition by CNS 
Wyniki przedstawione w tabeli 4 opierają się na rozwiązaniach podatku bankowego występujących w różnych państwach UE. Przeprowadzone badania wskazują, że wprowadzenie podatku bankowego w Polsce może dostarczyć do budżetu państwa dodatkowych środków pieniężnych w wysokości od $60 \mathrm{mln}$ zł do ponad 4,3 mld zł. Taka rozpiętość wpływów podatkowych wynika z tego, jaką konstrukcję podatku można by zastosować w polskim rozwiązaniu, przy czym zastosowanie w Polsce rozwiązania przewidzianego w ustawie mogłoby dostarczyć do budżetu dochodów podatkowych rzędu ponad 4,3 mld zł, co daje największy wpływ podatkowy z tytułu podatku bankowego. Najmniejsze wpływy do budżetu, w wysokości powyżej $60 \mathrm{mln}$ zł, występowałyby przy ustalaniu podstawy opodatkowania według rozwiązania niemieckiego przy zastosowaniu występującej tam stawki w wysokości $0,020 \%$.

Tabela 5 przedstawia wpływy z podatku bankowego w Polsce przy zastosowaniu różnych stawek podatku i jednolitej podstawy opodatkowania.

Wyniki przedstawione $\mathrm{w}$ tabeli 5 opierają się na różnych stawkach podatku występujących w państwach UE i jednocześnie na podstawie opodatkowania określonej w polskiej ustawie o podatku od niektórych instytucji finansowych. Wyniki badań wskazują, że wprowadzenie podatku bankowego może zasilić polski budżet dodatkowymi środkami finansowymi w wysokości od $130 \mathrm{mln}$ zł do ponad 4,3 mld zł. Taki przedział dochodów podatkowych wynika z możliwej do zastosowania $\mathrm{w}$ polskim rozwiązaniu stawki podatku, przy czym zastosowanie w Polsce stawki ustawowej $(0,0366 \%$ miesięcznie, czyli $0,4392 \%$ rocznie) dostarczyłoby do budżetu wpływów podatkowych rzędu ponad 4,3 mld zł. Polskie rozwiązanie dostarczy zatem największych dochodów do budżetu z tytułu podatku bankowego. Najniższe dochody podatkowe z tytułu obciążenia banków występowałyby przy zastosowaniu stawki w wysokości $0,010 \%$ jak w Portugalii $130 \mathrm{mln}$ zł.

Tabela 5. Podatek bankowy w Polsce przy zastosowaniu różnych stawek podatkowych i wskazanej w ustawie o podatku od niektórych instytucji finansowych podstawy opodatkowania

\begin{tabular}{|c|c|c|c|}
\hline Kraj & Stawka podatku [\%] & Podstawa opodatkowania w zł & Podatek w zł \\
\hline Polska & & \multirow{10}{*}{1303707093937,00} & 4341221000,00 \\
\hline \multirow{3}{*}{ Austria } & 0,055 & & 717038902,00 \\
\hline & 0,090 & & 1173336385,00 \\
\hline & 0,110 & & 1434077803,00 \\
\hline Belgia & 0,035 & & 456297483,00 \\
\hline Cypr & 0,150 & & 1955560641,00 \\
\hline Finlandia & 0,125 & & 1629633867,00 \\
\hline \multirow{2}{*}{ Francja } & 0,222 & & 2894229749,00 \\
\hline & 0,141 & & 1838227002,00 \\
\hline Holandia & 0,044 & & 573631121,00 \\
\hline
\end{tabular}




\begin{tabular}{|c|c|c|c|}
\hline Kraj & Stawka podatku [\%] & Podstawa opodatkowania w zł & Podatek w zł \\
\hline Łotwa & 0,072 & \multirow{18}{*}{1303707093937,00} & 938669108,00 \\
\hline \multirow{5}{*}{ Niemcy } & 0,020 & & 260741419,00 \\
\hline & 0,030 & & 391112128,00 \\
\hline & 0,040 & & 521482838,00 \\
\hline & 0,050 & & 651853547,00 \\
\hline & 0,060 & & 782224256,00 \\
\hline \multirow{2}{*}{ Portugalia } & 0,010 & & 130370709,00 \\
\hline & 0,085 & & 1108151030,00 \\
\hline Rumunia & 0,100 & & 1303707094,00 \\
\hline Słowacja & 0,200 & & 2607414188,00 \\
\hline Słowenia & 0,100 & & 1303707094,00 \\
\hline Szwecja & 0,036 & & 469334554,00 \\
\hline \multirow{2}{*}{ Węgry } & 0,150 & & 1955560641,00 \\
\hline & 0,210 & & 2737784897,00 \\
\hline \multirow{2}{*}{ Wielka Brytania } & 0,160 & & 2085931350,00 \\
\hline & 0,080 & & 1042965675,00 \\
\hline \multirow{2}{*}{ Włochy } & 0,100 & & 1303707094,00 \\
\hline & 0,200 & & 2607414188,00 \\
\hline
\end{tabular}

Źródło: opracowanie własne na podstawie Komisja Nadzoru Finansowego, 2018.

Tabela 6 przedstawia wysokość wpływów z podatku bankowego w Polsce przy zastosowaniu stawki podatkowej przewidzianej w ustawie oraz podstawy opodatkowania według przepisów różnych państw członkowskich UE.

Tabela 6. Podatek bankowy w Polsce przy zastosowaniu stawki podatkowej wskazanej w ustawie o podatku od niektórych instytucji finansowych i różnych podstaw opodatkowania

\begin{tabular}{|c|c|c|c|}
\hline Kraj & Stawka podatku [\%] & Podstawa opodatkowania w zł & Podatek w zł \\
\hline Polska & & & 4341221000,00 \\
\hline Austria & \multirow{8}{*}{0,4392} & 303558568032,00 & 1333229230,80 \\
\hline Belgia & & 303558568032,00 & 1333229230,80 \\
\hline Cypr & & 303558568032,00 & 1333229230,80 \\
\hline Finlandia & & 1042536847238,00 & 4578821833,07 \\
\hline Francja & & 1572873788133,00 & 6908061677,48 \\
\hline Holandia & & 303558568032,00 & 1333229230,80 \\
\hline Łotwa & & 303558568032,00 & 1333229230,80 \\
\hline Niemcy & & 303558568032,00 & 1333229230,80 \\
\hline
\end{tabular}

Ekonomia - Wroclaw Economic Review 26/, 2020

(C) for this edition by CNS 


\begin{tabular}{|c|c|c|c|}
\hline Kraj & Stawka podatku [\%] & Podstawa opodatkowania w zł & Podatek w zł \\
\hline Portugalia & \multirow{8}{*}{0,4392} & 303558568032,00 & 1333229230,80 \\
\hline Rumunia & & 507452222194,00 & 2228730159,88 \\
\hline Słowacja & & 303558568032,00 & 1333229230,80 \\
\hline Słowenia & & 1776767442 295,00 & 7803562606,56 \\
\hline Szwecja & & 1572873788133,00 & 6908061677,48 \\
\hline Węgry & & 1776767442295,00 & 7803562606,56 \\
\hline Wielka Brytania & & 303558568032,00 & 1333229230,80 \\
\hline Włochy & & 419265932703,00 & 1841415976,43 \\
\hline
\end{tabular}

Źródło: opracowanie własne na podstawie Komisja Nadzoru Finansowego, 2018.

Wyniki przedstawione w tabeli 6 opierają się na różnych sposobach określania podstawy opodatkowania występujących w państwach UE i jednocześnie na stawce podatkowej określonej w polskich przepisach. Przeprowadzone badania wskazują, że zastosowanie w konstrukcji podatku bankowego stawki przewidzianej w ustawie oraz różnych sposobów ustalania podstawy opodatkowania mogłoby przynieść do budżetu państwa dochody podatkowe rzędu od 1,3 mld zł do ponad 7,8 mld zł. Wpływy z podatku bankowego w Polsce wynoszą ponad 4,3 mld zł, co pod względem dokonanych obliczeń daje szóstą w kolejności wielkość dochodów podatkowych do budżetu. Największe wpływy podatkowe z tytułu opodatkowania banków - w wysokości ponad 7,8 mld zł - występowałyby przy określaniu podstawy opodatkowania zgodnie z zasadami panującymi w Słowenii (podstawę tworzą całkowite aktywa banku) i na Węgrzech (podstawą są aktywa netto). Wyższych wpływów budżetowych z tytułu opodatkowania banków dostarczyłoby również ustalanie podstawy opodatkowania według przepisów francuskich i szwedzkich (pasywa pomniejszone o fundusze własne) ponad 6,9 mld zł oraz finlandzkich (aktywa banku ważone ryzykiem) — ponad 4,5 mld zł. Natomiast najniższe wpływy podatkowe - w wysokości ponad 1,3 mld zł - występowałyby przy zastosowaniu rozwiązań z kilku państw (Austria, Belgia, Cypr, Holandia, Łotwa, Niemcy, Portugalia, Słowacja i Wielka Brytania), w których podstawę opodatkowania stanowią pasywa banku pomniejszone o fundusze własne i depozyty.

\section{Wnioski}

Z przeprowadzonej analizy wynika, że wprowadzenie podatku bankowego w Polsce niesie korzystne efekty fiskalne, ponieważ nowy podatek zapewnia dodatkowe wpływy do budżetu państwa. Oczywiście rozwiązanie to jest niekorzystne 
dla sektora finansowego, gdyż oznacza dodatkowe obciążenie banków. Nałożenie nowej daniny publicznej na banki powoduje, że obniżą się zyski netto banku, a to w dalszej perspektywie może przełożyć się na pogorszenie sytuacji ekonomicznej niektórych banków. Należy jednak zauważyć, że dodatkowe opodatkowanie banków, poza podatkiem dochodowym i VAT-em, występuje w kilku państwach członkowskich UE i nie wpłynęło znacząco na kondycję finansową samych banków ani całego sektora finansowego. Podatek bankowy bądź też opłata bankowa wprowadzone w większości wskazanych w artykule państw członkowskich UE przybierały zasadniczo formę podatku kryzysowego, to znaczy daniny publicznej nakładanej na podmioty w odpowiedzi na pojawienie się kryzysu ekonomicznego. W większości wpływy z tego tytułu zasilają budżet państwa, a tylko w kilku przypadkach fundusz stabilizacyjny. W Polsce podatek bankowy został nałożony na podmioty finansowe głównie w celu uzyskania dodatkowych wpływów budżetowych.

Wprowadzenie w Polsce podatku bankowego zgodnie z przepisami w ustawie o podatku od niektórych instytucji finansowych przyniosło w 2017 roku dodatkowe wpływy budżetowe rzędu ponad 4,3 mld zł. Przeprowadzona symulacja wskazuje, że zastosowanie przepisów ustawy daje wpływy podatkowe, które ogólnie są najwyższymi spośród występujących w państwach UE. Dla państwa jest to zatem korzystna sytuacja, dla sektora bankowego natomiast już niekoniecznie. Jeśli wziąć pod uwagę zastosowanie jednego z rozwiązań występujących $\mathrm{w}$ innych państwach UE, to znaczne wpływy z tytułu podatku bankowego występowałyby także przy zastosowaniu konstrukcji francuskiego i węgierskiego podatku (ponad 2 mld i 3 mld zł - wynika to z zastosowania w tych państwach dwóch stawek podatku). Najniższe dochody podatkowe $\mathrm{z}$ tego tytułu występowałyby natomiast przy zastosowaniu przepisów niemieckich $\mathrm{z}$ występującą tam najniższą stawką $0,02 \%$ (daje to wpływy rzędu zaledwie ponad $60 \mathrm{mln}$ zł). Zastosowanie jednego z rozwiązań występujących w UE wskazuje, że najbardziej opłacalny dla państwa okazuje się podatek pobierany według polskiej konstrukcji, a najmniej — według niemieckiej. Dla samego sektora bankowego sytuacja jest odwrotna.

Po uwzględnieniu stawek podatku występujących w różnych państwach unijnych oraz sposobu ustalania podstawy opodatkowania przewidzianego w polskiej ustawie z przeprowadzonych obliczeń wynika, że największe wpływy występowałyby przy zastosowaniu 0,222\% stawki francuskiej, 0,210\% węgierskiej i 0,200\% włoskiej. Najniższe dochody podatkowe z tego tytułu byłyby przy stawce $0,010 \%$, jak w Portugalii i $0,020 \%$ - w Niemczech. Warto przy tym zauważyć, że to podatek według polskiej konstrukcji dostarczyłby największych wpływów do budżetu. Korzystne byłoby również zastosowanie podstawy opodatkowania według polskich przepisów z najwyższą stawką francuską, węgierską lub włoską. Najmniej korzystna sytuacja zaistniałaby przy tej samej metodzie określania podstawy opodatkowania i stawce $0,020 \%$ lub $0,010 \%$. Dla sektora bankowego jednakże bardziej korzystna okazałaby się sytuacja odwrotna. 
Jeśli wziąć pod uwagę różne sposoby ustalania podstawy opodatkowania występujące w państwach UE i stawkę podatku przewidzianą w polskiej ustawie, to okazuje się, że największe wpływy podatkowe byłyby przy rozwiązaniu słoweńskim i węgierskim, a najniższe przy na przykład austriackim, belgijskim czy też niemieckim. Przeprowadzona symulacja wskazuje, że zastosowanie stawki podatku w wysokości $0,0366 \%$ miesięcznie $(0,4392 \%$ rocznie) i ustalanie podstawy opodatkowania jako całkowitych aktywów przynosi korzystniejsze efekty fiskalne dla państwa, a zarazem najmniej korzystne dla sektora bankowego. Natomiast zastosowanie tej samej stawki podatku, lecz z ustalaniem podstawy opodatkowania jako wartości pasywów pomniejszonych o fundusze własne i wartość depozytów, okazałoby się bardziej korzystne dla banków, ale zarazem byłoby najmniej korzystne dla państwa.

Wprowadzenie w Polsce podatku bankowego jest korzystnym rozwiązaniem dla państwa. Wprowadzenie nowej daniny publicznej przyniosło nowe dochody podatkowe do budżetu państwa rzędu 4,3 mld zł w 2017 roku. Można więc założyć, że w kolejnych latach wysokość wpływów z tego podatku będzie co najmniej na podobnym poziomie. Na podstawie przeprowadzonej symulacji można przy tym stwierdzić, że konstrukcja polskiego podatku od niektórych instytucji finansowych jest w sumie najkorzystniejszym rozwiązaniem dla państwa, a najmniej korzystnym dla sektora bankowego. W dalszej perspektywie warto rozważyć zmodyfikowanie konstrukcji podatku — na przykład o zmianę stawki podatku lub o sposób ustalania podstawy opodatkowania. Jednakowoż ewentualne zmiany $\mathrm{w}$ tej daninie publicznej powinny się wiązać z ustaleniem takiego rozwiązania, które z jednej strony dawałoby korzystne efekty fiskalne dla państwa (duże wpływy z tytułu podatku bankowego do budżetu), a z drugiej strony były jednocześnie korzystne dla sektora bankowego (nienadmierne obciążenie banków dodatkową daniną).

\section{Bibliografia}

Dec, P., Masiukiewicz, P. (2013). Podatek bankowy. Warszawa: C.H. Beck.

Gajewski, D.J. (2016). Podatek bankowy w Polsce — wady i zalety. Analizy i Studia, 1(1). Warszawa: Centrum Analiz i Studiów Podatkowych, Instytut Prawa SGH, Szkoła Główna Handlowa.

Juszczyk, S., Snarski, P. (2011). Przegląd potencjalnych podatków i opłat nakładanych na banki w obliczu globalnego kryzysu gospodarczego. Zeszyty Naukowe SGGW. Ekonomika i Organizacja Gospodarki Żywnościowej, 93, 43-56.

Kil, K., Ślusarczyk, R. (2014). Podatek bankowy w krajach Unii Europejskiej - ocena implementacji. W J. Sokołowski, A. Żabiński (red.), Polityka ekonomiczna (124-133). Wrocław: Wydawnictwo Uniwersytetu Ekonomicznego.

Komisja Europejska (2010). Taxation papers. Financial sector taxation. Working Paper, 25. Luxembourg: Office for Official Publications of the European Communities.

Komisja Nadzoru Finansowego (2018). Dane miesięczne sektora bankowego. Data dostępu: 26.11.2018, https://www.knf.gov.pl/?articleId=56224\&p_id=18.

Ekonomia - Wroclaw Economic Review 26/, 2020

(C) for this edition by CNS 
Marcinkowska, M. (2011). Dodatkowe podatki i opłaty od banków — potrzeby praktyki i dylematy teorii finansów. W K. Jajuga (red.), Finanse - nowe wyzwania teorii i praktyki. Problemy wiodace (100-127). Wrocław: Wydawnictwo Uniwersytetu Ekonomicznego.

Martysz, C.B., Bartlewski, B. (2018). Podatek bankowy - koncepcja europejska i studium przypadków wybranych krajów UE. W K. Marchewka-Bartkowiak (red.), Nowa architektura europejskiego systemu finansowego (101-133). Studia BAS, 1(53). Warszawa: Wydawnictwo Sejmowe Kancelarii Sejmu.

Narodowy Bank Polski (15.10.2010). Wybrane aspekty dodatkowego opodatkowania banków w kontekście debaty na forum Unii Europejskiej. Warszawa.

Siudek, T. (2011). Podatek bankowy — konsekwencje dla sektora bankowego w Polsce. Zeszyty Naukowe SGGW. Ekonomika i Organizacja Gospodarki Żywnościowej, 92, 63-76.

Siudek, T. (2012). Podatek bankowy jako instrument wspierania stabilności finansowej. W A. Alińska, B. Pietrzak (red.), Stabilność systemu finansowego - instytucje, instrumenty, uwarunkowania (359-372). Warszawa: CeDeWu.pl.

Sprawozdanie z wykonania budżetu państwa za okres od 1 stycznia do 31 grudnia 2017 r. (2018). Warszawa: Rada Ministrów.

Syta, P. (2016). Regulacja prawna podatku bankowego w Polsce. W W. Bożek (red.), System podatkowy w Polsce. Jego rola i znaczenie w procesach gospodarowania (341-353). Szczecin: Wydział Prawa i Administracji, Uniwersytet Szczeciński.

Szolno-Koguc, J., Twarowska, M. (2015). Dodatkowe daniny publiczne sektora finansowego (banków) - przegląd międzynarodowy. Lublin: ALTERUM Ośrodek Badań i Analiz Systemu Finansowego.

Ustawa z dnia 15 stycznia 2016 r. o podatku od niektórych instytucji finansowych, Dz.U. z 2016 r. poz. 68 .

Wojciuk, M. (2017). Wpływ podatku od niektórych instytucji finansowych na zachowania banków komercyjnych w Polsce. Optimum Studia Ekonomiczne, 6(90), 27-41.

Zygierewicz, M. (2012). Podatek od transakcji finansowych a podatek od działalności finansowej. W I. Pyka, J. Cichorska (red.), Finanse w niestabilnym otoczeniu - dylematy $i$ wyzwania. Bankowość (492-505). Katowice: Wydawnictwo Uniwersytetu Ekonomicznego. 